\title{
Prostorske podobe v obrednih praksah starozaveznih očakov in njihov pomen za razumevanje krščanskega sakralnega prostora
}

\author{
Spatial Images in the Ritual Praxis of the Old \\ Testament Patriarchs and Their Significance for \\ Understanding of the Christian Sacral Space
}

Izvleček: Problemsko jedro raziskave so prostorske podobe, ki se pojavljajo v starozaveznih zapisih o obrednih dejanjih očakov: Abrahama, Izaka in Jakoba. Po tipologiji se kažejo kot zaokrožena celota, umeščena med zapise o vesoljnem potopu in Jahvejeva navodila za izdelavo shodnega šotora. Po izgubljenem raju jih je mogoče razumeti kot človekov poskus ponovne vzpostavitve pristne komunikacije s transcendenco. Z uporabo literarne, arhetipske in primerjalne analize nameravamo pokazati sorodnost med obravnavanimi prostorskimi ureditvami in krščanstvom (kot novonastajajoče religije) oz. njegovim iskanjem lastnega obrednega prostora.

Ključne besede: arhitektura, sakralna arhitektura, stara zaveza, arhetipi, Abraham, Izak, Jakob

\begin{abstract}
The core problem of the present research are spatial images which appear in the Old Testament descriptions of ritual acts of the patriarchs Abraham, Isac, and Jacob. According to typology they represent a recognizable whole placed between biblical descriptions of the flood and Jahve's instructions for building the tent of his dwelling. After man's expulsion from Eden, these ritual acts can be understood as his attempt to re-establish friendship with Transcendence. With the use of literary, archetypical, and comparative analysis we want to present relationship between considered spatial images and attempts of Christianity (as a new religion) to find its own ritual space.
\end{abstract}

Key Words: Christianity, architecture, sacral architecture, Old Testament, archetypes, Abraham, Isaac, Jacob 


\section{Uvod}

Bistvena značilnost arhitekture je kompleksnost. Vedno znova se sooča z enigmo ravnotežja med kompleksnostjo uporabnikovih bivalnih potreb, kompleksnostjo zagotavljanja konstrukcijske varnosti, trdnosti in trajnosti dane prostorske rešitve ter kompleksnostjo regulacije njune interakcije, po kateri zaživi celota v edinstveni estetski prepričljivosti, v realnem, vedno kompleksnem prostoru in času. Ko govorimo o krščanski sakralni arhitekturi (oziroma sakralni arhitekturi nasploh), je treba dodati grozdu kompleksnosti še »jagodo« razvojnih zakonitosti, določeno s tisočletno navzočnostjo tega stavbnega tipa v življenju krščanstva (oziroma religije). Zgoščenost problemskih plasti, s katero se sooča sakralna arhitektura, se v slednji kaže kot bogata raznolikost. Zaradi očitnosti te zgoščenosti $\mathrm{v}$ analitskih prikazih pogosto prevlada nad njenimi sicer zastrtimi, a toliko bolj pomembnimi skupnimi potezami. Za odkrivanje prostorskih prvin v krščanski sakralni arhitekturi, v katerih prepoznavamo skupne korenine sakralne arhitekture, imajo starozavezna biblična besedila posebno vrednost. Prostorske podobe v njih razkrivajo človekove napore, da bi s prostorskimi (arhitekturnimi) ureditvami izostril in poglobil doživljanje njegove slutnje Presežnega.

Problemsko sidrišče prispevka so biblični zapisi o življenju in delovanju starozaveznih očakov ter zlasti o oblikah njihove komunikacije s transcendenco. Osmišlja jih gotovost božje obljube o vzniku velikega naroda in njemu pripadajočega prostora - obljubljene dežele. Ob radikalno spremenjenem odnosu Bog-človek po človekovi izgubi raja in končno po izničenju stvarstva z vesoljnim potopom se odpira vprašanje, na kakšne načine in $\mathrm{v}$ kakšni meri prostor, še posebej oblikovani prostor, sooblikuje ta odnos. Z vidika motrenja prostorskih ureditev, v katerih so starozavezni očaki prepoznavali bližino Božjega, se biblična besedila na eni strani kažejo kot zamejena z zapisom o izgonu človeka iz raja, na drugi pa z zgodbo o Abrahamu kot nekakšen preludij k problemskemu jedru tega prispevka. Njegov osrednji vsebinski del se tako nanaša na analitski prikaz prostorskih ureditev, ki so jih uporabljali Abraham, Izak in Jakob v njihovi komunikaciji z Bogom, kot jih lahko razberemo iz besedil Prve Mojzesove knjige. V sklepnem delu pa bodo predstavljene najpomembnejše značilnosti obravnavanih prostorskih ureditev, pri čemer bo posvečena pozornost 
razbiranju arhitekturnih arhetipskih prvin, v katerih moremo prepoznati korenine nekaterih prostorskih rešitev krščanskega sakralnega prostora.

Poleg deskriptivne metode in metode literarne analize je bil kot orodje za obravnavo besedil na ravni arhitekturne analize vključen tudi model arhitekturnih arhetipov. Ta daje prednost razločevanju skupnih potez pred izpostavljanjem raznolikosti (Debevec 2016, 201-275) s ciljem pokazati na prisotnost starozaveznih prostorskih reminscenc v krščanski sakralni arhitekturi.

\section{Daritev kot izraz človekovega iskanja božje bližine}

Prvo biblično besedilo, ki nas uvede v obravnavano problematiko, je zgodba o Adamovih potomcih Kajnu in Abelu (1 Mz 4,1-16). Spada v jahvistično tradicijo (SPJ 2014, 53). Med njuno zgodbo in edenskim idiličnim sožitjem Stvarnika s človekom zija zaradi človekove samovolje nepremostljiv prepad. Človek je obsojen na od Stvarnika prekleto zemljo (1 Mz 3,1719). Stvarstvo, naravni prostor zunaj edena, postane zaradi stvarnikovega prekletstva človeku tuje, celo sovražno. Človek doživi osamljenost v novovzpostavljeni oddaljenosti od Stvarnika. Kljub tej tragični ločenosti pa, kot lahko razberemo iz zgodbe o Kajnu in Abelu, v njem ne ugasne potreba po nekakšnem stiku s transcendentno realnostjo. V obravnavanem besedilu jo prepoznavamo v suhoparnem zapisu, da je bil Abel »pastir drobnice, Kajn pa je bil poljedelec. Ko je preteklo nekaj časa, je Kajn daroval GOSPODU daritev od sadov zemlje. Tudi Abel je daroval od svoje drobnice, njihovo tolščo.«(1 Mz 4,3-4) Pred nami je prvi zapis v bibličnih besedilih o novi obliki človekove komunikacije z Bogom - daritvi. Tako Kajn kot Abel nista darovala po ukazu oziroma na pobudo Stvarnika, temveč, če smemo sklepati iz zapisa, iz očitne lastne potrebe po vzpostavitvi odnosa z Bogom. Na slednje kaže tudi različnost darov; Kajn daruje sadove zemlje, Abel - tolščo prvencev drobnice. Na Kajnovo in Abelovo samoiniciativnost napeljuje tudi v besedilu uporabljen izraz minhâ, s pomeni: darilo, dar oziroma žrtev (Averbeck 2003, 708.713). O samem kraju darovanja in njegovi morebitni ureditvi ne izvemo ničesar. Vsekakor se opisana drama dogaja zunaj edenskega vrta. V edenskem vrtu daritev ni bilo. Za problem, ki ga obravnava ta razprava pa je bistvenega pomena, da Stvarnik verificira daritev Adamovih potomcev kot obliko komunikacije, 
a hkrati v vsebinskem pogledu selektivno: „GOSPOD se je ozrl na Abela in njegovo daritev, na Kajna in na njegovo daritev pa se ni ozrl." (1 Mz 4,4-5) Ob številnih teoloških vprašanjih, ki jih odpira božja selektivnost do darovalcev, sta za obravnavani problem pomembni dve spoznanji; prvič, da se daritev kot človekova pobuda v iskanju božje bližine izkaže za učinkovito ter drugič, da sam akt darovanja nosi v sebi tako zametke obrednosti kot tudi nujnost posebne prostorske ureditve.

Grobe obrise slednje nam razkriva zgodba o Noetu (1 Mz 6,5-9,17). Čeprav se ob branju zgodbe o Kajnu in Abelu zdi, da je Stvarnik z izgonom človeka iz raja in prekletstvom stvarstva vzpostavil dokončni okvir človekovega bivanja, prinese zgodba o Noetu dramatični preobrat. Ob razrastu človekove hudobije Stvarnik ponovno prevzame pobudo z odločitvijo, da bo izničil stvarstvo z vesoljnim potopom, pri čemer pa se odloči ohraniti »kal življenja». Izbere Noeta, ki »je hodil z Bogom« (1 Mz 6,9) (kar spominja na edensko intimno prijateljstvo človeka in Stvarnika), njegovo družino in od vsega, kar živi, od vsega mesa po dvoje od vsake vrste, samca in samico (1 Mz 6,19) (oziroma po fragmentu besedila druge tradicije od čistih živali po sedem parov, od nečistih pa enega (1 Mz 7,2)). Opis potopa ne pušča nobenega dvoma o popolnem uničenju: »Pomrlo je vse, kar ima dih življenja v sebi, vse, kar je bilo na suhem. [...] Ostal je samo Noe in kar je bilo z njim na ladji.« (1 Mz 7,22-23) Stvarnikova naklonjenost Noetu je očitna. Ko se pred potopom Noe vkrca na plovilo (o njegovih arhitekturnih in arhetipskih značilnostih glej: Debevec 2019, 205-207), Stvarnik skrbno zapre vrata za njim $(1 \mathrm{Mz} 7,16)$ in mu po apokaliptični povodnji pove, kdaj naj se izkrca (1 Mz 8,15). Prvo Noetovo dejanje ob izkrcanju v novem stvarstvu je postavitev oltarja: »Noe je postavil GOSPODU oltar in vzel od vseh čistih živali in od vseh čistih ptic ter daroval žgalne daritve na oltarju." (1 Mz 8,20) V opisu daritve se že kažejo prvine obrednosti. Nanjo spominja izbor (obredno) čistih živali. Tudi kraj žrtvovanja ni več poljuben. Po eni strani je poseben že zaradi dejstva, da je na tem mestu človek prvič stopil v novo stvarstvo; v tem pogledu označuje oltar točko, topos, od koder se življenje, ne več iz nič (ex nihilo), temveč iz »kapsule« (plovila), ponovno razširi po stvarstvu; po drugi strani pa je poseben, ker je prva človekova (Noetova) intervencija v novem stvarstvu oziroma akt njegovega preoblikovanja postavitev oltarja, žrtvenika za daritev Stvarniku. Noetova daritev je bila zahvalna, in ne spravna, saj je našel še pred potopom »milost v GOSPODOVIH očeh« (1 Mz 6,8) (Whybray 2000,47). 
Primernost in učinkovitost Noetovega obrednega ravnanja je potrdil sam Stvarnik, ki je "zaduhal prijetni vonj« in rekel sam pri sebi, da ne bo nikoli več preklel zemlje zaradi človeka (1 Mz 8, 21). Čeprav je novo stvarstvo »oprano«Stvarnikovega prekletstva in Bog blagoslovi Noeta, nima več kakovosti edenskega vrta. Z vesoljnim potopom je uničen tudi rajski vrt, ki ga je Stvarnik ob stvarjenju zasadil, da bi se v njem družil s človekom (Debevec 2019, 208). Tako postane v stvarstvu po potopu oltar (žrtvenik) kraj najpristnejše komunikacije človeka s transcendenco.

S stališča razbiranja prostorskih podob v bibličnih besedilih je v zgodbi o Noetu zanimivo tudi Stvarnikovo sklepno dejanje: sklenitev zaveze z Noetom - izraz brezpogojne božje naklonjenosti človeku. Za učinkovito vidno znamenje slednje se izkaže naravni pojav - mavrica: »Svojo mavrico postavim v oblake in bo v znamenje zaveze med menoj in zemljo." (1Mz $9,13)$ Izbor je vreden podrobnejšega motrenja. Vsekakor ima mavrica kot naraven pojav lastnosti, prilegajoče se transcendentni realnosti. V sušnosti krajev, kjer so nastala obravnavana besedila, je bila mavrica gotovo redek, če že ne izjemen pojav. Nastane s koincidenco razpršenih kapljic vode po ozračju in (zunajzemeljske) sončne svetlobe. Mavrica se pojavi naenkrat brez predhodnih znamenj, ki bi napovedovala gotovost takega pojava. Na enak način tudi izgine. Njene razsežnosti so praviloma impozantne, osupne s svojo barvitostjo, a je hkrati v svoji prosojnosti neulovljiva. V naravnem okolju, v katerem ni grajenih struktur, pa je gotovo fascinantna zaradi svoje kontrastne geomerijske čistosti polkrožnega loka. Za razliko od edenskega vrta, v katerem se je Stvarnik družil s človekom, prepoznava človek v novem stvarstvu njegovo navzočnost prek različnih znamenj, med katerimi je prvo mavrica.

\section{Abrahamova »udomačitev« prostora obljubljene dežele}

Sklop bibličnih besedil o očaku Abrahamu (1 Mz 12,1-25,18) je relativno bogat s prostorskimi podobami, ki kažejo postopno kultiviranje prostorskih in obrednih prvin komunikacije starozaveznega človeka s transcendenco. V obravnavani materiji prepoznavamo, grobo gledano, dva sklopa prostorskih podob. Značilnost prvega je njihova očitna povezanost z vzpostavljanjem obljubljene dežele kot prostorske realnosti. Podobe 
drugega sklopa pa so v prvi vrsti izraz Abrahamove vedno bolj intimne povezanosti z Bogom. V tej hierarhiji bodo obravnavane v nadaljevanju.

Tako kot pri reševanju Noeta pred apokaliptično povodnjijo je tudi pri projektu uresničitve obljubljene dežele pobuda na stani Boga. Bog izbere in pokliče Abrahama. Naroči mu, naj zapusti svoj dom ter se odpravi v deželo, ki mu jo bo pokazal (1 Mz 12,1). Naročilo ni brez razloga, saj ga spremlja obljuba, da bo iz Abrahama naredil velik narod (1 Mz 12,2). Tako kot Noe tudi Abraham posluša božji glas in se odpravi v Kánaansko deželo. Abraham jo fizično izkusi tako, da jo prehodi (1 Mz 12,6-7). Ob pozornem branju obravnavanega besedila se pokaže, da se je Abraham pri njegovem prvem ogledu obljubljene dežele dosledno izogibal takratnih mest in stikom z domačini Kanaanske dežele, saj je živel v šotoru kot potujoči tujec (Whybray 2000, 52). Če se je Abraham pri ogledovanju prostora božje obljube trudil vzbujati pri domačinih čim manj pozornosti, pa so njegovi prvi posegi $\mathrm{v}$ ta prostor kontrastno samozavestni.

Prvi tak je povezan z njegovim prihodom k Moréjevem hrastu v bližini Sihema. Moréjev hrast je bil že pred prihodom Abrahama pomembno Kanaansko kultno središče ( $\operatorname{Rad} 1972,162$ ). Hrast je veljal za sveto drevo, pri katerem so se razglašale prerokbe, če smemo sklepati iz izraza mōreh »ta, ki uči« (Whybray 2000, 49). Po bibličnem izročilu se je Abrahamu na tem kraju prvič prikazal Jahve z obljubo, da bo ta dežela dom njegovih potomcev (1 Mz 12,6-7). Abraham označi mesto božjega prikazovanja s postavitvijo oltarja. Tako v popolni tajnosti vzpostavi zametek prvega Jahveju posvečenega svetiščnega kompleksa v obljubljeni deželi.

Naslednje dejanje Abrahamovega udomačevanja prostora obljubljene dežele je postavitev oltarja med Betelom in Ajem (1 Mz 12,8). Tako kot pri Moréjevem hrastu postavi tudi tu oltar na lastno pobudo, pri čemer v prvem primeru označi z oltarjem kraj božjega prikazovanja, tu pa postavi oltar z namenom, da bo ob njem »klical Gospodovo ime« $(12,8)$. Biblični zapis o Abrahamovi vrnitvi na ta kraj po »egipčanski epizodi«(1 Mz 13,3-4) je pomenljiv z vidika obravnavane teme, saj kaže Abrahamovo zavestno željo po utrditvi na novo vzpostavljenih svetih krajev v prostoru obljubljene dežele kot krajev posebne božje bližine. Zato se Abraham vrača na isti kraj. 
Zametke tretjega svetiščnega kompleksa vzpostavi Abraham po prijateljski ločitvi od nečaka Lota. Z vsem, kar je imel, se je utaboril pri Mamrejevih hrastih (današnji Râmet el-Khalîl) v bližini Hebrona (1 Mz 13,18). Tudi tu postavi oltar Gospodu. Posebnost in pomen tega kraja stopnjuje Božje prikazanje Abrahamu, v besedilu »naslikano« z obiskom treh mož (1 Mz 18,2). V primerjavi z dosedanjimi opisi komunikacije med Bogom in Abrahamom v vzpostavljenih svetih krajih slednji izstopa v vsaj dveh pogledih. Prvi se tiče komunikacije med Abrahamom in Bogom (1 Mz 18,38). V njej moremo prepoznati prvine nekdanjega edenskega sožitja med Bogom in človekom. To namreč ne poteka več v obliki samogovorov enega ali drugega, temveč kot pogovor - dialog. Drugega pa določa Jahvejeva napoved čudežnega spočetja pri že ostareli Sari. Pomen čudežnosti spočetja samega po sebi tu izjemno naraste, ker božja obljuba o izvoljenosti dobi z napovedanim pravim Abrahamovim potomcem poleg vse jasnejših prostorskih obrisov tudi otipljivost obljubljene številnosti naroda, ki bo poselil ta prostor.

Obravnavani opisi Abrahamovega vzpostavljanja svetih krajev v obljubljeni deželi po mnenju poznavalcev pripadajo najstarejši jahvistični tradiciji (SPJ 2014, 66). Zapis o Beeršebi, o kateri bo govor v nadaljevanju, pa je del elohistične tradicije (80). Če je Abraham doslej predstavljene svete kraje v Kánaanu zaznamoval, vsaj po bibličnih besedilih sodeč, brez vednosti ali celo pristanka domačinov, pa je situacija v zvezi Beeršebo drugačna. Abraham se namreč tu zaplete v spor z domačini - Abimélehovimi hlapci zaradi vodnjaka, ki so si ga s silo prilastili (1 Mz 21,25). Z zavezo z Abimélehom, katere podlaga je bila Abrahamova prisega, da je vodnjak izkopal sam (Be'ér šéba'; vodnjak prisege ali vodnjak sedmih jagnjic), si je pridobil pravico do posesti vodnjaka, kar je bilo za nomada izjemnega pomena, saj mu je ta pravica zagotavljala možnost ustalitve (Thomas 2020, 271; SPJ 2014, 80). Abrahamu je uspel majhen, a sila pomemben korak, v katerem je komaj verjetna Jahvejeva obljuba dobila prvi obris otipljive gotovosti. Abrahamova posestna pravica na vodnjaku v Beeršébi ima tudi pomembno simbolno težo, saj je ta kraj po pregovorni biblični rabi zveze »od Dana do Beeršébe«(Sod 20,1) štel za kraj na južni meji Kanaana (Smith 1901). Zanimivo je, da Abraham pridobljene pravice v Beeršébi ne označi s postavitvijo oltarja, temveč z zasaditvijo trdoživega in vednozelenega drevesa tamariske, pri kateri kliče Gospodovo ime. Drevo je poleg vode v puščavskih krajih vsekakor učinkovit simbol za trajno počastitev zvestega 
Boga, ki ga Abraham zdaj prepoznava kot »večnega Boga«(1 Mz 21,33) (Thomas 2020, 271).

Najpomembnejši Abrahamov korak pri vzpostavljanju svetih krajev v obljubljeni deželi pa sproži smrt njegove žene Sare. Zanimiva pripoved o Abrahamovem iskanju prostora za pokop je del duhovniške tradicije (SPJ 2014, 82). Kot tujec in priseljenec se Abraham obrne na domačine, Hetove sinove, s prošnjo za kos zemlje, kamor bi pokopal svojo ženo. V bibličnem besedilu (1 Mz 23,3-18), ki opisuje značilno orientalsko pogajanje, izstopata dve stvari, pomembni za obravnavano temo. Abraham kot tujec in priseljenec ne prepusti domačinom odločitve o tem, kje lahko pokoplje ženo Saro. Takoj ko Hetovi sinovi pokažejo načelno pripravljenost na pogajanje o tem, postane Abraham zelo konkreten: »Če vam je prav, da spravim svojega mrliča od doma in ga pokopljem, me poslušajte in prosite zame Coharjevega sina Efróna, naj mi dá votlino Mahpélo, ki jo ima na koncu svojega polja. Za polno ceno srebra naj mi jo dá v vaši sredini za grobišče.» (1 Mz 23,8-9) Očitno je, da Abrahamova prošnja ni zgolj izraz stiske, v kateri se je znašel ob ženini smrti, temveč hkrati vnaprej domišljeno ravnanje. Vtis premišljenosti dodatno krepi druga posebnost obravnavanega besedila, namreč Abrahamovo vztrajanje, da želeno posest pošteno plača. Cena je bila astronomsko visoka v primerjavi z na primer 40 šekli srebra, ki jih je plačal kralj David Arávnu za zemljišče, na katerem je bil kasneje zgrajen tempelj (2 Sam 24,24) (Constable 2020, 285). Morebiti je bil njen namen odvrniti Abrahama od nakupa. Pomenljivo je, da Abraham to neobičajno visoko ceno brez obotavljanja poravna in zapečati kupčijo: "Tako je prešlo Efrónovo polje, ki je v Mahpéli nasproti Mamreju, polje z votlino, ki je bila na njem, in vse drevje, ki je bilo na polju, na vsem ozemlju naokrog, Abrahamu v last vpričo Hetejcev, vseh, ki so prihajali k vratom njegovega mesta." (1 Mz 23,17-18) Opisano Abrahamovo ravnanje ima pomembne posledice. V deželi, ki mu jo je Bog obljubil, je vzpostavljena nekropola kot ena najpomembnejših konstitutivnih prvin istovetnosti bodočega izraelskega naroda. Nekropola kot izsek prostora tuje dežele v lasti Abrahama je njemu in vsem, ki z njim sledijo Božji obljubi, neizpodbiten dokaz njene resničnosti. Ko Abraham umre, ga položijo k večnemu počitku k Sari, ne več kot tujca, temveč kot domačina obljubljene dežele, zaenkrat še zgoščene v obseg Maphélijeve nekropole. Sleherni pokop na tem kraju močno stopnjuje pomen nekropole kot osrednjega sidrišča obljubljene dežele. 
Skupna značilnost doslej obravnavanih svetih krajev, ki jih vzpostavlja Abraham v obljubljeni deželi, je, da je določitev njihove mikrolokacije znotraj obljubljene dežele prepuščena Abrahamovi presoji. Izjema v tem pogledu je elohistična pripoved o drami Abrahamovega darovanja svojega sina Izaka (1 Mz 22,1-19). V tem primeru je Jahve tisti, ki naroči Abrahamu: „Vzemi svojega sina, svojega edinca, ki ga ljubiš, Izaka, pojdi v pokrajino Moríja in ga tam daruj v žgalno daritev na eni od gora, za katero ti bom povedal." (1 Mz 22,2) Ko sta prišla na kraj, "za katerega mu je Bog povedal, je Abraham tam postavil oltar in naložil drva. Potem je zvezal svojega sina Izaka in ga položil na oltar, zgoraj na drva.« (1 Mz 22,9) Bog določi kraj žrtvovanja. Abraham tam postavi oltar. Kasnejša tradicija je prepoznala Morijo v vzpetini, na kateri je kasneje kralj Salomon zgradil jeruzalemski tempelj, čeprav v bibličnih besedilih ni nobenega trdnega argumenta za tako sklepanje (Whybray 2000, 54). Bolj verjetno je, da je bila vzpostavljena povezava krajev v obratni smeri z namenom dati toposu Salomonovega templja simbolni pedigre očakov (James 1992, 905).

\subsection{Prostorske podobe kot izraz premen v komunikaciji med Bogom in Abrahamom}

V dosedanjih predstavitvah smo bili priča različnim oblikam komunikacije med Abrahamom in Bogom. Prevladuje samogovor, v besedilih formuliran kot »Gospod je rekel«, oziroma ko gre za Abrahama, »je klical Gospodovo ime«. S stališča obravnavanega problema je zanimiva predvsem redkeje uporabljena oblika Božjega nagovora, pri kateri se Bog "prikaže» Abrahamu. Tako je bilo v zvezi z nastajajočim svetiščnim kompleksom pri Mamrejevih hrastih že omenjeno, da se je Bog razodel Abrahamu v podobi treh mož (angelov?). Čeprav lahko iz besedil le redkokdaj razberemo, kakšno čutno zaznavno podobo so si nadele te božje teofanije (razodetja), so tiste, ki so v besedilih opisane, zlasti če nosijo prostorske karakteristike, toliko dragocenejše. Med slednje moremo nedvomno uvrstiti besedilo o Božji enostranski zavezi Abrahamu (1 Mz 15,7-17). Da bi Jahve pokazal Abrahamu trdnost svoje obljube, mu naroči, naj razpolovi telico, kozo in ovna in s temi polovicami oblikuje nekakšen špalir ter doda še nerazpolovljeni grlico in goloba (1 Mz 15, 9-11). Ko se je stemnilo, je doživel Abraham dramatičen prizor. »Kadeča peč in goreča plamenica» sta se premikali skozi tako oblikovan špalir (1 Mz 15, 17). V predstavljenih podobah se kažejo prvine $\mathrm{v}$ tedanji kulturi znanega starega obreda zaveze, 
pri katerem so njeni sklenitelji stopali med kosi krvavečega mesa in klicali usodo teh žrtev nase, če bi prekršili obljubljeno (SPJ 2014, 71). Zlasti sta zanimivi podobi dima in ognja kot znamenji Jahvejeve navzočnosti, ki se pogosto pojavljata v bibličnih opisih potovanja Izraelcev v obljubljeno deželo pod vodstvom Mojzesa.

\section{Izakovo utrjevanje svetih krajev}

Čeprav je biblično besedilo o očaku Izaku v primerjavi s tistima, ki opisujeta življenjsko pot Abrahama ali kasneje Jakoba, opazno krajše, prinaša v zvezi z obravnavano temo nekaj pomembnih drobcev. Vsi se nanašajo na njegovo bivanje v okolici Beeršébe. V 1 Mz 26,15-18 izvemo za iznajdljivost Abrahama, ki je, očitno potem ko je pridobil posestno pravico na vodnjaku v Beeršébi, dal izkopati še nekaj vodnjakov v Gerárski dolini. Kot preberemo v obravnavanem besedilu, so domačini po Abrahamovi smrti zasuli te vodnjake. Izak pa jih da obnoviti in jih ponovno poimenuje tako, kot jih je poimenoval njegov oče. Izakova skrb za prostorsko kontinuiteto je očitna, saj vrača prostor v stanje, ki ga je vzpostavil njegov oče. Hkrati pa tudi sam nadaljuje očetovo prakso. Tudi Izak prihaja pri kopanju novih vodnjakov v konflikt z domačini (1 Mz 26,19-21). Šele tretji vodnjak ni povzročil konflikta, $v$ čemer je Izak prepoznal božje posredovanje in priložnost za utrditev ter razširitev posestne pravice na tem pomembnem kraju: »Resnično, zdaj nam je GOSPOD naredil prostor, da lahko rastemo v deželi." (1 Mz 26,22) Izak nadene vodnjaku pomenljivo ime Rehobót, kar pomeni »svoboden prostor« (SPJ 2014, 89).

Pomen Beeršébe kot svetega kraja stopnjuje Jahvejeva teofanija v času enega izmed Izakovih obiskov tega kraja. V njej mu Bog obljubi varstvo in številno potomstvo (1 Mz 26,24). Izak označi to pomembno doživetje s postavitvijo oltarja, pri katerem po zgledu svojega očeta kliče Gospodovo ime. V tem dejanju vzpostavlja obredno prakso, ki sama po sebi utrjuje svetost kraja. Tu izkoplje tudi vodnjak (1 Mz 26,25), kar ponovno kaže na povezavo simbolizma vode s svetostjo kraja. 


\section{Jakobovo dograjevanje svetih krajev}

Prvo, kar lahko izluščimo iz svetopisemskih besedil o očaku Jakobu v zvezi z obravnavano temo, je, da nadaljuje premišljeno prakso svojih prednikov pri postopnem prostorskem »udomačevanju« obljubljene dežele. Spoštuje svete kraje svojih prednikov. Po smrti očeta Izaka tako ostaja v Beeršébi. Zaradi v času Abrahama in Izaka pridobljene posestne pravice na vodnjakih se Jakob v Beeršébi ne počuti več kot popoln tujec v tuji deželi. Tamkajšnje svetišče se zato toliko učinkoviteje vrašča v kolektivni spomin njegovih rojakov kot eno izmed sidrišč istovetnosti ljudstva, ki bo nekoč zasedlo obljubljeno deželo. Tu se Jakob, tedaj že imenovan Izrael, ponovno ustavi na svoji poti v Egipt k sinu Jožefu. Biblični zapis o Jakobovih klavnih daritvah Bogu v Beeršébi (1 Mz 46,1) na tej poti priča o postopnem razvoju obrednih praks, ki šele v Mojzesovih časih dobijo prvo kodificirano obliko.

Nizu svetih krajev v obljubljeni deželi doda Jakob še svojega. Od sinov Hamórja kupi zemljišče pred Sihemom, se na njem utabori in postavi oltar. Poimenuje ga El, Izraelov Bog (1 Mz 33,19-20). Poleg nekropole, ki jo je vzpostavil Abraham na kupljenem Efrónovem polju v Mahpéli nasproti Mamreju, je pridobil Jakob s kupčijo v last drugi kos bodoče domovine naroda, ki bo izšel iz njega.

V času Jakoba začne med dotlej vzpostavljenimi svetimi kraji izstopati pomen svetišča v Betelu. Že prvi biblični zapis o očaku Jakobu prinaša opis, povezan s tem svetim krajem (1 Mz 28,10-19). Na poti iz Beeršébe v Harán ga je tu zalotila noč. Po mnenju nekaterih biblicistov naj bi bil to kraj, na katerem je nekoč že Abraham postavil oltar. Opirajo se na izraz maqom, ki podobno kot soroden arabski izraz maqam pomeni sveti prostor oziroma svetišče (Ewing 1939). Če to drži, je neobičajno, da biblično besedilo, sicer preplet elohistične in jahvistične tradicije, govori zgolj o "nekem kraju«, kjer je Jakob prenočil, še bolj pa Jakobovo začudenje naslednjega jutra: »Resnično, GOSPOD je na tem kraju in jaz nisem vedel.» (1 Mz 28,16) Zdi se, kot bi ne poznal svetega kraja, ki ga je vzpostavil že Abraham. Posebnost kraja se Jakobu razodene v sanjah: „Glej, lestvica je bila postavljena na zemljo, njen vrh pa je segal do neba in Božji angeli so hodili gor in dol.« (1 Mz 28,12) Doživi tudi božjo navzočnost z obljubo posedovanja dežele, v kateri se nahaja, božjega varstva in številnega potomstva (1 Mz 28,13-15). Zaradi posebnosti nočnega doživetja je zanj kraj 
svet: »Kako strah vzbujajoč je ta kraj! To ni nič drugega kakor hiša Božja in to so vrata nebeška!« (1 Mz 28,17) Zanimivo je, da Jakob ne označi posebnosti kraja, kjer je doživel božjo bližino, z oltarjem, tako kot sta to počela Abraham in Izak, temveč s kamnom, ki ga je imel za vzglavje, "postavil ga je za spomenik in nanj zlil olje« (1 Mz 28,18). Če drži domneva, da je Jakob prespal na svetem kraju, vzpostavljenem že v času Abrahama, je zelo verjetno, da je Jakobova stela del Abrahamovega »svetišča». Postavljanje stel - spominskih kamnov je bilo sicer razširjeno tudi v sosednjih kulturah, zlasti mezopotamski in egipčanski. Podobno tudi sanjska podoba lestve oziroma stopnic med nebom in zemljo spominja na mezopotamski zigurat in egipčansko stopničasto piramido kot najbolj impozantna arhitekturna poudarka tamkajšnjih svetiščnih kompleksov. V obeh kulturah sta bila močan arhitekturni simbol stika človeške in božanske realnosti (Wightman $2007,73)$. Tu se prvič srečamo s pomenljivo obredno prakso maziljenja. Z maziljenjem (z zlitjem olja na kamen) je bil kamen izvzet iz profane rabe in postal posvečen, zato pa tudi za človeka nedotakljiv kot pomnik posebne Božje navzočnosti.

V doslej obravnavanih besedilih je bil predvsem Bog tisti, ki je dajal obljube. Jakob prekine to prakso in tudi sam obljubi Bogu: "Ta kamen, ki sem ga postavil za spomenik, bo Božja hiša in od vsega, kar mi boš dal, ti bom zagotovo daroval desetino. (1 Mz 28,22) Svetišče v Betelu je tako materialni izraz božjega varstva na eni strani ter človekovega zaupanja vanj na drugi. Za kako pomemben premik v komunikaciji med Bogom in človekom gre, pokaže Božje prikazanje Jakobu v času njegovega bivanja pri Labánu. Predstavi se mu z besedami: »Jaz sem Bog iz Betela, kjer si mi pomazilil spomenik in kjer si mi dal obljubo. (1 Mz 31,13) Za našo razpravo je zlasti pomemben kakovostni premik v zvezi s svetiščem v Betelu. Slednje ni zgolj sveti kraj, na katerem sta Jakob in njegov prednik Abraham izkusila božjo bližino, temveč hkrati kraj, ki ga tudi Bog posvoji za kraj svoje bližine s človekom. Opisano posebnost svetišča dodatno razkriva biblični odlomek 1 Mz 35,1-15. Uvede ga Božje naročilo Jakobu: »Vzdigni se, pojdi v Betel in tam prebivaj. Tam napravi oltar Bogu, ki se ti je prikazal, ko si bežal pred svojim bratom Ezavom.« (1 Mz 35,1) Pri pripravah na odhod iz Sihema Jakob naroči: „Odpravite tuje bogove, ki so med vami. Očistite se in preoblecite se« $(1 \mathrm{Mz} 35,2)$ in s tem »v svoji hiši« uvede dotlej še nepoznano obredno prakso, povezano z obiskom svetega kraja - očiščenje. Kipce bogov in uhane zakoplje Jakob pod hrast pri Sihemu (1 Mz 35,4). 
Hrast, ki ga omenja besedilo, bi lahko bil Mamréjev hrast, poganski kultni prostor, pri katerem je nekoč Abraham ob svojem prvem obisku kanaanske dežele postavil oltar (Ewing 1939). Ko Jakob prispe v Betel, izpolni božje naročilo in mu sezida oltar.

Obravnavano besedilo opisuje še en pomenljiv dogodek, ki daje svetišču v Betelu vse večji pomen. Po vrnitvi iz Padán Aráma je Jakob tu znova priča božji teofaniji. Bog ga blagoslovi, obnovi obljubo in ga preimenuje v Izraela. Tudi v tem primeru Jakob označi kraj božje teofanije s kamnitim spomenikom (po vsej verjetnosti kamnito stelo), na katerega zlije pitno daritev in ga oblije z oljem (1 Mz 35,14). Božje preimenovanje Jakoba moremo razumeti kot pomembno znamenje »njegovi hiši« o božjem izpolnjevanju dane obljube o narodu, ki bo poselil obljubljeno deželo. Svetišče v Betelu postaja s tem simbolnim dejanjem zibelka nastajajočega izraelskega naroda.

Z vidika razbiranja prostorskih podob v bibličnih besedilih o starozaveznih očakih je zanimiv še opis sporazumne razmejitve prostora med Jakobom in njegovim stricem Labánom v gorovju Gilead (1 Mz 31, 45-54), saj ima, glede na izpeljavo, elemente svetega kraja. Jakob označi mejo najprej s spominskim kamnom, še najbolj podobnim mejniku (Rigsby 2003, 465). Hkrati na tem kraju s pomočjo bratov postavi kamnito gomilo, da bi bila označitev razmejitve kar se da vidna in trajna. Na to kaže tudi Jakobovo poimenovanje te ureditve z izrazom "Galeéd «, v prevodu "gomila pričevanja« (SPJ 2014, 100). Dokončnost oziroma nedotakljivost razmejitve in z njo povezane prostorske označitve je "sakralizirana« s skupnim obedom na kupu ter kasneje še s klavno daritvijo (1 Mz 31,54). Iz besedila ni mogoče razbrati, ali je bila za obred uporabljena obravnavana ureditev ali pa je, glede na obravnavano vrstico, zanj Jakob izbral katerega od okoliških vrhov.

Jakobovo utrjevanje svetih krajev v obljubljeni kanaanski deželi zaokrožuje njegova želja, da ga, ko umre, položijo k počitku v nekropolo na polju Mahpéli (1 Mz 49,29-31). Tu poleg Jakoba počivajo že Abraham z ženo Saro, Izak z ženo Rebeko in njegova prva žena Lea. Z Jakobovim pokopom postaja nekropola poleg svetišča v Betelu nesporno drugo najpomembnejše sidrišče istovetnosti izraelskega naroda. 


\section{Arhitekturne arhetipske prvine svetih krajev Abrahama, Izaka in Jakoba}

Ko pogledamo na celoto predstavljenih prostorskih podob, ki se nam razkrivajo v obravnavanih bibličnih besedilih, moremo iz nje izluščiti nekatere značilnosti. Zaradi preglednosti bodo obravnavane z nekaterih za to razpravo pomembnih vidikov: $z$ vidika svojega etiološkega ozadja, z vidika obrednih praks, ki so jih očaki prakticirali na svetih krajih, ter Z vidika njihovih arhitekturnih značilnosti, da v njih poiščemo morebitne arhitekturne arhetipske prvine.

\subsection{Etiološko ozadje svetih krajev}

Iskanje vzgibov za vzpostavitev posameznega svetega kraja v obravnavanih besedilih pokaže tri. Statistično najpogostejši je očakova lastna pobuda. To velja za svete kraje, ki jih vzpostavi Abraham med Betelom in Ajem, pri Mamrejevih hrastih ter za nekropolo na Mahpélijevem polju. Isto velja tudi za Izakovo postavitev oltarja v Sihemu. Drug, po številu skoraj enakovreden vzgib je božja teofanija. Slednja določa prvi sveti kraj v obljubljeni deželi pri Morejevem hrastu, nato Beeršébo, botruje pa tudi Jakobovi vzpostavitvi pomembnega svetišča v Betelu. Pripomnimo, da so očaki deležni božje teofanije tudi na drugih že vzpostavljenih svetih krajih (pri Mamrejevih hrastih in v Sihemu), kar kaže na pomemben moment božje "posvojitve« dotičnega svetega kraja. Tretji vzgib pa je neposredno božje naročilo. Kot primarni vzrok se pojavi samo enkrat, in sicer v zvezi z goro v pokrajini Moríja, na kateri naj bi Abraham daroval svojega prvorojenca Izaka. Neposrednemu Božjemu naročilu smo sicer priča tudi v zvezi s svetiščem v Betelu, a je Jakob na tem kraju že pred tem doživel božjo teofanijo.

Čeprav so predstavljene etiologije z vidika razmerja med človekom in transcendenco zanimive same po sebi, se njihov pravi pomen skriva v razmerju teh svetih krajev do edinstvenega prostora - obljubljene dežele. Priznani religiolog Mircea Eliade v zvezi s tem ugotavlja arhetipski mehanizem, po katerem je vsaka naselitev v novi oziroma nekultivirani deželi enakovredna aktu stvarjenja. V skladu s tem mehanizmom je vsako ozemlje, zasedeno z namenom naselitve oziroma uporabljeno kot življenjski prostor, najprej preoblikovano iz kaosa v kozmos (Eliade 1959, 10-11). Sledi te logike so vidne tudi v opisanih ravnanjih Abrahama, Izaka in Jakoba. 
Sveti kraji, ki jih vzpostavijo, so potemtakem najprej sami po sebi »mikrokozmosi«, torej prostori realnosti obljubljene dežele. S svojo vse prej kot naključno razporeditvijo po prostoru pa določajo najpomembnejša (najsvetejša) oprijemala, preko katerih obljubljena dežela tudi kot celota, čeprav še nezasedena, zaživi v prepričljivi resničnosti. Tudi sama logika preoblikovanja prostora iz kaosa v kozmos z vzpostavitvijo svetih krajev je po naravi arhetipična. Dogaja se namreč v navezi človek-transcendenca, zaradi katere preoblikovani prostor ni zgolj fizično obvladani izsek realnega snovnega prostora, temveč nosi istovetnost transcendentnega vzora, v našem primeru istovetnost izgubljenega raja. Reminiscenco najdemo že pri Lotu pred njegovo ločitvijo od Abrahama (1 Mz 13,10). Nanjo pa spominja tudi na svetih krajih vse bolj sproščena komunikacija med očaki in Bogom, v kateri začetne samogovore enega ali drugega zamenja pogovor, ki po intimnosti spominja na edensko sobivanje Stvarnika s človekom.

\subsection{Obredne prakse}

Obravnavana biblična besedila razkrivajo celo pahljačo preprostih obrednih praks, s katerimi so njihovi akterji vzpostavljali komunikacijo s transcendenco. Med najpogostejšimi je daritev. Predmet daritve so poljščine (Kajn), živali (Abel, Noe, Abraham, Jakob), pijača (Jakob) in celo človek (Abraham). Poleg darovanja očaki na svetih krajih »kličejo Gospodovo ime«. Biblični zapis o Jakobu dodaja predstavljeni dvojici še maziljenje, očiščenje in obed. Čeprav v teh preprostih obrednih dejanjih razbiramo sledi obrednih praks sosednjih ljudstev, s katerimi so prihajali v stik, moremo v predstavljeni raznolikosti videti najprej izraz prvobitne človekove religioznosti, v kateri se kažejo prve poteze bodočega religijskega profila. Z vračanjem očakov na večino vzpostavljenih svetih krajev se postopno utrjuje učinek brezčasnosti kraja, saj v ponavljajoči obredni rabi zaživi vse, kar se je zgodilo na tem kraju, kot hkratna celota. Vzpostavitev svetega kraja ni zaključena zgolj z določitvijo realnega snovnega prostora in z njegovo ustrezno ureditvijo (postavitev oltarja, zasaditev drevesa), temveč je za njegovo zaresnost nujno obredje, saj je preko njegovega učinka izbranemu prostoru dana forma, po kateri postane kot sveti kraj tudi resničen (Eliade 1959, 11). 


\subsection{Arhitekturne značilnosti}

Med očitnimi prostorskimi značilnostmi obravnavanih svetih krajev je posebnost lokacije. To lahko določa njen položaj v odnosu do širšega prostora. Taka je na primer Beeršéba na južnem robu obljubljene dežele. Lahko jo določa že predhodna sveta raba, kot velja za svetišče pri Moréjevem hrastu, ali pa prisotnost naravne posebnosti na takem kraju, kot sta votlina na Efrónovem polju ter prisotnost vode (Beeršéba). Prostorskim karakteristikam je treba dodati še izpostavljenost take lokacije na vzpetini oziroma gori (gora v pokrajini Moríja, na kateri je daroval Abraham).

Informacije o arhitekturni podobi svetih krajev so v obravnavanih besedilih pričakovano skope. To je razumljivo, saj očaki šele vzpostavljajo svetiščna jedra bodoče domovine. Najpogosteje označijo sveti kraj z oltarjem. Podrobnejših opisov tovrstnih ureditev v obravnavanih besedilih ni. V obliki predpisov se pojavijo šele v Mojzesovem času. Besedila govore, da je ta ali oni očak »postavil« oltar Gospodu. Po vsej verjetnosti so bili taki oltarji nekakšni kupi kamenja, nabranega na samem kraju oziroma v njegovi neposredni bližini, in urejeni v bolj ali manj pravilno obliko, primerno za preprosto obredje. Edina izjema je očak Jakob. Po Božjem navodilu se vrne iz Sihema v Betel in tam »sezida« oltar. Podrobnejša raziskava o tem, ali gre tu zgolj za svobodo prevajalca ali pa je hitro naraščajoči pomen svetišča v Betelu že vplival na trajnejšo in monumentalnejšo zasnovo oltarja, bi presegla zastavljeni okvir razprave. Podobno velja za kamnite stele, s katerimi se v bibličnih besedilih prvič srečamo pri očaku Jakobu. Sama ureditev je preprostejša od oltarja. Gre za večji kamen - monolit, ki, postavljen pokončno, označuje kraj. Višji ko je, učinkoviteje označuje posebnost kraja in njegovo prepoznavnost $\mathrm{v}$ širšem prostoru. Obe ureditvi povezuje simbolizem žrtve, zahvale in spomina. Povsem drugače uredi Abraham kraj ob prvem obisku Beeršébe. Zasadi drevo in izkoplje vodnjak. Ureditev ima elemente svetega gaja, poznana tako v mezopotamski in grški kot tudi kasnejši rimski religiji. Za razliko od oltarja in stele je tu prisoten simbolizem življenja, trdoživosti in rasti.

Ko sicer skromne zapise soočimo s strukturo arhitekturnih arhetipov sakralnega (Debevec 2016, 201-275), se nam pokažejo vsaj trije. Prvi arhetip je mreža. Sveti kraji, ki so jih vzpostavili Abraham, Izak in Jakob, nanešeni na karto prostora svojega delovanja, tvorijo s svojo linijsko 
razporeditvijo med Sihemom na severu in Beeršébo na jugu svetiščno hrbtenico obljubljene dežele. Nadaljnje analize ostalih starozaveznih besedil, ki želijo osvetliti razvoj obravanih svetiščnih kompleksov ter morebitnega dograjevanja zastavljene mreže, bodo šele pokazale pravo težo take interpretacije. Drugi očiten arhetip je lokacija. Podobno kot pri drugih antičnih ljudstvih je tudi pri starozaveznih očakih vzpostavitev svetih krajev prvi korak k posedovanju tujega prostora. Analiza besedil o njihovem nastanku je pokazala, da niso rezultat nakjučnih ravnanj očakov, temveč jih določa edinstvenost dogodkov, povezanih z vzpostavitvijo obljubljene dežele kot bodoče domovine izraelskega naroda. Njihovo posebnost dograjujejo že predstavljene naravne karakteristike. Tretji arhetip, ki ga z lahkoto prepoznamo v obravnavanih besedilih, pa je presveto. Splošna značilnost arhaičnih svetiščnih kompleksov katerekoli kulture je njihova preprostost, $v$ kateri pa nikoli ne umanjka artikulirana točka presvetega. Med njenimi najpogostejšimi »arhitekturnimi« intepretacijami je prav oltar oziroma žrtvenik. Slednje velja tudi za obravnavane svete kraje. Oltar je glavni, če že ne edini snovni označevalec sakralne provenience takega kraja. Čeprav sta, strogo gledano, Beeršéba in Betel najprej označena prva z zasaditvijo drevesa, drugi pa s postavitvijo stele, je kmalu zatem na obeh krajih postavljen oltar, ki določi njuni obredni žarišči.

Končno so s stališča obravnavanega problema zanimive tudi teofanije, zlasti tiste, ki si nadevajo vidni izraz. Mednje moremo uvrstiti ogenj in dim, ki jima je bil priča Abraham ob sklenitvi zaveze, tri može (angele), ki so ga obiskali pri Mamrejevih hrastih, oziroma moža, s katerim se je boril Jakob (1 Mz 32,25-30). Vsaj pogojno lahko v nabor teofanij pridužimo še mavrico kot vidni izraz božje navzočnosti - naklonjenosti Noetu. Tudi naštete "vizualizacije« transcendence imajo skupno arhetipsko ozadje lika. Njihovo raznolikost moremo pripisati arhaičnosti prepletajočih se religioznih tradicij v bibličnem izročilu in nakazujejo smeri postopne profilacije v okviru nastajajoče judovske religije.

\section{Arhitekturne reminiscence obravnavanih svetih krajev v krščanskem sakralnem kompleksu}

Ugotovljena arhetipska podstat glavnih »arhitekturnih" značilnosti sicer elementarno skromnih ureditev svetih krajev sama po sebi povezuje starozavezno "prostorsko« izročilo z ostalimi religijami. V naslovu postavljena 
korelacija obravnavanega problema s krščanskim sakralnim prostorom terja napovedano zožitev. Krščanstvo se je že kot mlada religija zavedalo, da je poleg spreobrnjenja duš pomembno tudi "pokristjanjenje " prostora. Učinkovit mehanizem pri zasledovanju zastavljenega cilja je vzpostavitev mreže sakralnih kompleksov. Med očitne primere te vrste moremo uvrstiti mrežo božjepotnih cerkva. Temeljni vzgib njenega razvoja je bila pobožnost čaščenja svetnikov, izvorno vezana na kraje njihovega pokopa, kmalu pa je bila s pomočjo »izuma« relikvij premišljeno tkana po celotnem krščanskem svetu. Podobna je narava mreže lastniških cerkva na pragu srednjega veka. Nastajala je kot izraz medsebojne povezanosti cerkvene in fevdalne oblasti v projektu misijonskega oznanjevanja. Ne nazadnje je tudi razmah meniškega življenja prispeval k rasti številnih mrež samostanov, preko katerih so posamezni redovi uresničevali svoje karizme.

Podobno moremo v krščanski arhitekturi tudi v obravnavi lokacije prepoznati nekatere sorodnosti z obravnavano starozavezno tradicijo. Najdemo jo lahko v ravnanju Abrahama, ki v obljubljeni deželi vzpostavi prvi sveti kraj na že obstoječem preročišču pri Moréjevem hrastu. Tudi krščanstvo razume pomen vraščenosti antičnih svetiščnih kompleksov v kolektivni zavesti družbe, v katero vstopa kot nova religija. Take kraje najpogosteje preplasti s krščanskim sakralnim kompleksom. Privilegiran status med lokacijami krščanskih sakralnih kompleksov imajo že od samega začetka kraji, povezani z Jezusovim življenjem, kraji, povezani z delovanjem njegovih učencev, pa tudi grobovi svetnikov, kar spominja na starozavezni pomen krajev božjega razodevanja oziroma pomen nekropole očakov na Efrónovem polju za istovetnost izraelskega naroda. V obdobjih življenja Cerkve, v katerih je zavestno razkazovala svojo institucionalno moč, se tudi pri obravnavi lokacije krepi pomen njene prostorske dominantnosti oziroma izpostavljenosti.

Krščanski sakralni kompleks se na ravni arhitekturne interpretacije obravnavanih arhetipov najbolj približa starozavezni tradiciji v obravnavi presvetega. Tako kot obravnavane svete kraje tudi krščanski sakralni kompleks osredinja oltar. Prostorsko najbolj učinkovito je ta osredinjenost uresničena v zgodnjekrščanski baziliki, v kateri se celoten prostor z vsemi njegovimi členitvami zgošča v enem samem oltarju kot njegovemu glavnemu bežišču. Čeprav je oltar v kasnejših reinterpretacijah kompleksa kot celote 
doživljal številne premene tako glede njegove oblike, položaja kot tudi števila, je vedno ostal glavno žarišče obrednega dogajanja.

Končno moremo govoriti o arhetipski sorodnosti krščanskega sakralnega kompleksa s starozavezno tradicijo v zvezi z že omenjenim motivom raja, ki mu v podtonu sledimo skozi vsa obravnavana biblična besedila. Starozavezni očaki so vzpostavljali svete kraje kot tusvetne prostorske fragmente izgubljenega raja, ki bodo s poselitvijo obljubljene dežele zaživeli kot celota. V krščanskem sakralnem kompleksu pa moremo z motivom raja povezati značilno dvojnost obrednega prostora, v katerem je ta arhitekturno interpretiran s prezbiterijem in edinim oltarjem, postavljenem v njem. Opisana teološka matrica prepričljivo zaživi v vzhodni Cerkvi na velikonočno vigilijo s slovesnim obredjem odpiranja cesarskih vrat v ikonostasu. Odprta srednja vrata ikonostasa, skozi katera je v velikončnem tednu do bele nedelje verniku omogočen nezastrt pogled v prezbiterij simbolno kažejo na veličino Kristusovega vstajenja, saj verniku odpira pot v raj.

\section{Sklep}

Motrenje bibličnih besedil o obrednih praksah starozaveznih očakov Abrahama, Izaka in Jakoba razkriva, da je človek prepoznal v specifično urejenem prostoru edinstveni potencial, zaradi katerega je zaživela njegova komunikacija s transcendenco v novi, prepričljivejši kakovosti. Primerjalna analiza svetih krajev, s katerimi so očaki premišljeno udomačevali prostor svoje bodoče domovine, pokaže skupne značilnosti tako na etiološki in obredni ravni kot tudi na ravni arhitekturnih značilnosti. Čeprav elementarno skromni, že nosijo v sebi značilna arhetipska jedra, zaradi katerih njihov pomen prerašča okvir judovske tradicije, saj dograjujejo bogastvo arhitekturnih interpretacij sakralnega prostora. Arhetipska podstat arhitekturnih značilnosti obravnavanih svetih krajev nakazuje možne smeri njihove sorodnosti s krščanskim sakralnim prostorom. V pričujoči razpravi so te smeri zgolj nakazane, saj si vsaka od njih zasluži samostojno obravnavo. Podobno bo šele nadaljnje raziskovanje besedil starozaveznega kanona pokazalo pravi pomen svetih krajev oziroma njihovo pomensko hierarhijo, predvsem pa njihovo vlogo tako za dokončno vzpostavitev obljubljene dežele - prostorskega okvirja izraelskega naroda kot tudi za izoblikovanje istovetnosti svetiščnega kompleksa judovske religije. Povsem samostojno 
arhitekturno obravnavo si zasluži tudi motiv mesta. Kot človekova tvorba je mesto v obravnavanih besedilih povezano s tujostjo, kaosom (Sodoma in Gomora) in nečimrnostjo (Babilonski stolp).

Živimo čas, v katerem se realnost snovnosti, ob vznesenem zmagoslavju tehnologije, vse hitreje razblinja v najrazličnejših virtualnih podatkovnih oblakih. Zdi se, kot da snovna zaresnost prostora, tako naravnega kot arhitekturnega, izgublja mik in celo smisel, zaradi česar postaja človek siromašnejši za pomembno, če že ne bistveno sidrišče svoje istovetnosti, ki jo v čedalje večji meri določa poljubnost. Slednja je še posebej boleča na polju človekove artikulacije prostorov njegove komunikacije s transcendenco. Biblično izročilo o očakih Abrahamu, Izaku in Jakobu nasprotno pokaže, da postane prav snovnost obljubljene dežele in z njo povezana vzpostavitev svetih krajev učinkoviti okvir, učinkovita infrastruktura nove kakovosti odnosa med Bogom in človekom. V prispevku tematizirani arhitekturni mehanizmi oživljanja tega zastonjskega latentnega potenciala prostora naj bodo povabilo k ponovni tenkočutnosti ter z njo povezanemu spoštovanju pomenske kompleksnosti prostorov obrednega sobivanja Boga in človeka.

\section{Kratica}

SPJ Sveto Pismo. Peteroknjižje: jeruzalemska izdaja. 2014. Ljubljana: Družina, Teološka fakulteta.

\section{Reference}

Averbeck, Richard E. 2003. Sacrifices and offerings. V: Dictionary of the Old Testament: Pentateuch, 706-733. Downes Grove: InterVarsity Press.

Bethel. 1980. In: The Cyclopedia of Biblical, Theological, and Ecclesiastical Literature.

https://www.biblicalcyclopedia.com/B/bethel.html (pridobljeno 17. 5. 2020).

Constable, L. Thomas. 2020. Notes on Genesis. https://planobiblechapel.org/tcon/ notes/pdf/genesis.pdf (pridobljeno 10. 8. 2020).
Debevec, Leon. 2016. Toward Sacral Architecture. Beograd: Faculty of Ortodox Theology, the Institute for Liturgy and Church Art; the Institute for Sacral Architecture.

- - -. 2019. Genealogija prostora v bibličnih besedilih: Stvarjenje. Edinost in dialog 74/1: 195-212.

https://doi.org/10.34291/edinost/74/debevec

Eliade, Mircea. 1959. Cosmos and History. New York: Harper \& Brothers.

Ewing, E. 1939. Bethel. V: International Standard Bible Encyclopedia Online. https://www.internationalstandardbible.com/B/ bethel.html (pridobljeno 13. 8. 2020). 
Ewing, W. 1939. Shechem. V: International Standard Bible Encyclopedia Online. https://www.internationalstandardbible.com/s/ shechem.html (pridobljeno 13. 8. 2020).

Hawk, L. Daniel. 2003. Altars. V: Dictionary of the Old Testament: Pentateuch, 33-37. Downes Grove: InterVarsity Press.

James, R. Davila. 1992. Moriah. V: The Anchor Bible Dictionary, zv. 4, k-n, 905. New York: Doubleday.

Masterman, E. W. G. 1939. Beersheba. V: International Standard Bible Encyclopedia Online.

https:/www.internationalstandardbible.com/B/ beersheba.html (pridobljeno 13. 8. 2020).
Rad, von Gerhard. 1972. Genesis. London: SCM Press Ltd.

Rigsby, R. O. 2003. Jacob. V: Dictionary of the Old Testament: Pentateuch, 461-467. Downes Grove: InterVarsity Press.

Smith, William. 1901. Beersheba. V: Smith's Bible Dictionary, 77. New York: Pillar Books.

Sveto pismo. Peteroknjižje:jeruzalemska izdaja. 2014. Ljubljana: Teološka fakulteta; Družina.

Whybray, Roger Norman. 2000. Genesis. V: The Oxford Bible Commentary, 38-66. New York: Oxford University Press.

Wightman, G.J. 2007. Sacred spaces. Leuven: Peeters. 